\title{
THE RELATIONSHIP BETWEEN ROMANIAN EXPORTS AND ECONOMIC GROWTH AFTER THE ADHESION TO EUROPEAN UNION
}

\author{
Ramona Dumitriu \\ rdumitriu@ugal.ro \\ Razvan Stefanescu \\ rstefanescu@ugal.ro \\ Dunarea de Jos University of Galati, Romania
}

\begin{abstract}
This paper explores the relationship between the quarterly values of the Romanian exports and of the Gross Domestic Product for the period 2007 - 2014, which was marked by the consequences of the adhesion to European Union and by the global crisis. In this analysis we employ cointegration tests, Vector Autoregression (VAR) and Granger causality techniques. The results indicate no cointegration between the two variables but a causal effect of exports on the Gross Domestic Product.
\end{abstract}

Keywords: Exports, Economic growth, Granger Causality

JEL classification codes: F43, 040, 049

\section{Introduction}

In the last years the world economy evolution led to new approaches of the relationship between the international trade and the economic growth. The globalization process increased the role of the international trade, while the dramatic consequences of the recent global crisis highlighted the necessity of rethinking the economic growth importance as an objective of the macroeconomic policies. In these circumstances, the relationship between economic growth, usually quantified by the variation of the Gross Domestic Product (GDP), and international trade became a major theme from the macroeconomics literature.

The impact of the international trade on a national economy was highly approached by the classic economic theories. Adam Smith (1770) viewed the international trade as a significant factor of labor division and productivity. The theory of comparative advantages, developed by David Ricardo (1817), assigned to the international trade a major impact on the national economy's evolution. In the Keynesian model (1936) the net exports are included in the expenditure expression of the output.

There are two main hypotheses regarding the relationship between economic growth and international trade: the Exports-Led Growth Hypothesis (ELGH) and the Growth-Led Exports Hypothesis (GLEH). ELGH stipulated that exports could stimulate economic growth by several channels. Firms that are involved in export activities could improve their performances by learning from external clients and competitors (Clerides et al., 1996; Aw et al., 1998; Bernard \& Jensen, 1999; Wagner, 2005; De Loecker, 2010). Foreign markets offer to exporters the economies of scale opportunities, reducing the per-unit costs, because of larger quantities produced (Krugman, 1980; Sokoloff, 1984; Helpman and Krugman, 1985; Helpman, 1999). The real wages raise, one of the exports' effects, could stimulate the economic growth by increasing the domestic demand (Bernard \& Jensen, 1999; Schank et al., 2008). Facing the competition from external markets, exporters have to invest in modern technologies leading to capital formation (Rodrik, 1988; Aw et al., 1998). Finally, exports could surpass the foreign exchange constraint that affects the efficiency of many firms from the less developed countries (Voivodas, 1973; Jung \& Marshall, 1985).

GLEH regards the causality from economic growth to exports. Some processes that accompany the economic growth, such as the improvement of employees' skill, the acquisition of new technology or the increase of the management efficiency, could stimulate the exports (Bhagwati \& Srinivasan, 1979; Krugman, 1984; Barro, 1991). Empirical researches investigated both ELGH and GLEH. Some of them found, for several countries, evidences in favor of ELGH (Emery, 1967; Syron \& Walsh, 1968; Serven, 1968; Kravis, 1970; Michaely, 1977; Balassa, 1978). There are also researches that indicated the validity of GLEH for some countries (Sharma \& Dhakal, 1994; Ahmad \& Harnhirun, 1996; Mehrara \& Firouzjaee, 2011; Abbas, 2012).

In this paper we approach the relationship between the Romanian exports and the economic growth during the period 2007 - 2014. After the adhesion to European Union (EU), in 2007, new opportunities to access the European markets were offered to the Romanian exporters. However, the postadhesion period was also marked by the consequences of the global crisis. We investigate the ELGH and 
GLEH by employing cointegration tests, Vector Autoregression (VAR) and Granger causality techniques. The rest of the paper is organized as it follows: the second part describes the data and methodology employed to investigate the relationship between exports and GDP, the third part presents the empirical results and the fourth part concludes.

\section{Data and Methodology}

In this investigation we employ quarterly values of the exports provided by the National Bank of Romania (NBR) and of the gross domestic product, provided by the National Institute of Statistics (NIS) from Romania. Our sample of data covers a period of time from January 2007 to December 2014. We calculate GDP in constant 2005 local currency units, dividing the nominal values by the GDP deflator, provided by NIS. We convert the exports, which are expressed in euro, to the local currency units using the quarterly exchange rates provided by NBR. Then we deflate these values using foreign trade index price provided by NIS. For the purpose of this investigation we employ, for each variable, two types of time series: natural logarithms and the first differences of natural logarithms. We use the following abbreviations of data:

- 1_RGDP natural logarithms of the real gross domestic product;

- 1_REXP natural logarithms of the real exports of good and services;

- d_l_RGDP, first differences of I_RGDP;

- d_l_REXP, first differences of l_REXP.

The Figure 1 presents the evolution of the four time series between 2007 and 2014. Their values are susceptible to a quarterly seasonality which has to be taken into account in this investigation.
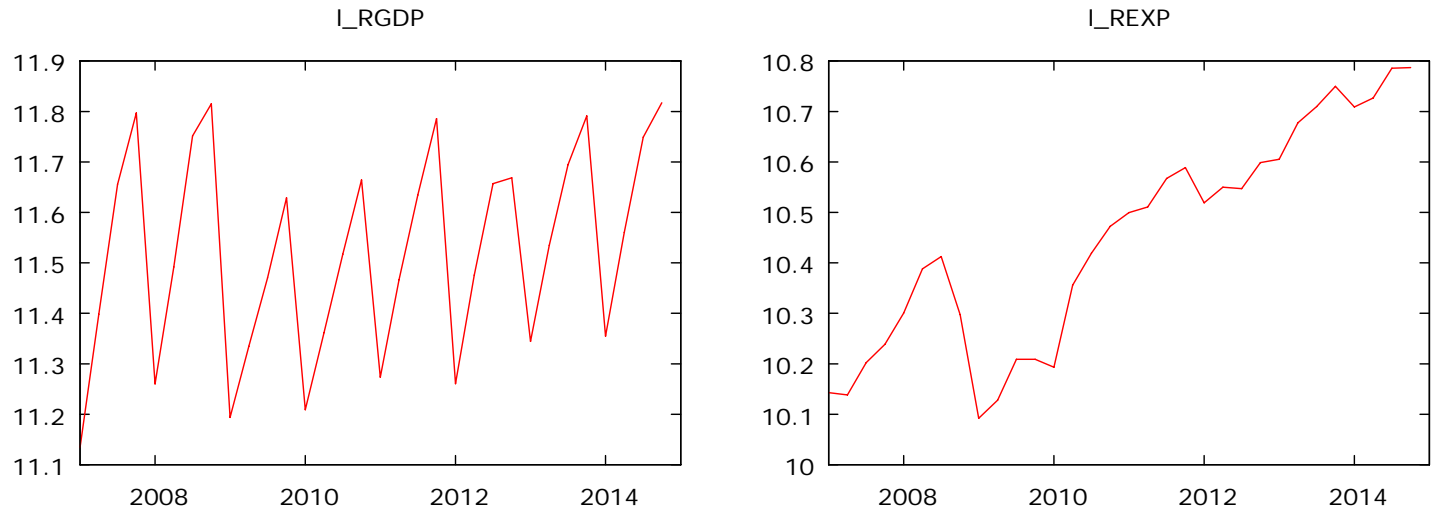

d_I_RGDP
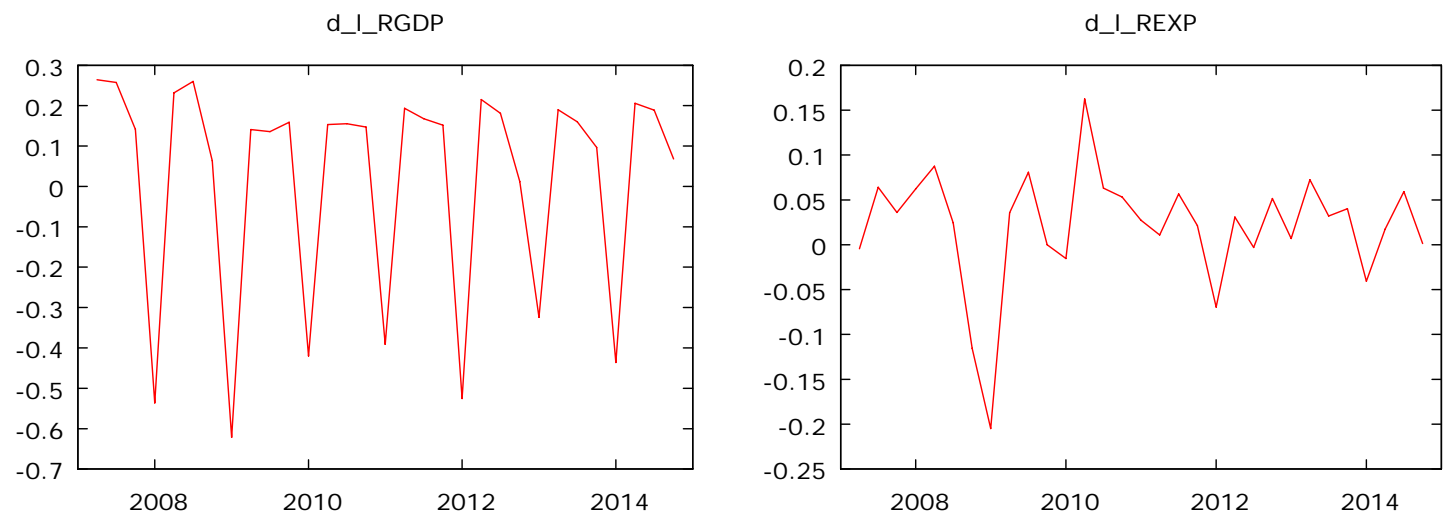

Figure 1. Evolution of l_RGDP, l_REXP, d_l_RGDP and d_l_REXP between 2007 and 2014

In order to perform cointegration and VAR regressions we analyze the stationarity of the four time series by employing the Augmented Dickey - Fuller (ADF) unit root test (Dickey \& Fuller, 1979). For this test we use, based on the graphical representations, two forms of regressions:

- regressions with constant plus seasonal dummies as deterministic term;

- regressions with constant and trend plus seasonal dummies as deterministic term. 
The first form of regression is described by the equation:

$\Delta y_{t}=\mu_{0}+\sum_{j=1}^{k} \rho_{k} \times \Delta y_{t-k}+\sum_{l=1}^{3} \lambda_{l} \times S_{l}+\varepsilon_{t}$

where:

- $\Delta$ is an operator for difference;

- $\mu_{0}$ is a constant term;

- $\mathrm{k}$ is the number of lags;

- $\rho_{\mathrm{k}}$ is the coefficient of the k-lagged differences of the variable $\mathrm{y}$;

- $\mathrm{S}_{\mathrm{l}}$ is a seasonal dummy variable associated to the quarter $\mathrm{l}$;

$-\lambda_{1}$ is the coefficient of the seasonal dummy variable associated to the quarter 1 ;

- $\varepsilon_{\mathrm{t}}$ is an error term.

The second form of regression is described by the equation:

$\Delta y_{t}=\mu_{0}+\mu_{1} \times t+\sum_{j=1}^{k} \rho_{k} \times \Delta y_{t-k}+\sum_{l=1}^{3} \lambda_{l} \times S_{l}+\varepsilon_{t}$

where:

- $\mu_{1}$ is a coefficient associated to the trend variable;

- $\mathrm{t}$ is the trend variable.

We select the number of lags of the ADF regressions using three information criteria:

- the Akaike Information Criterion (AIC) proposed by Akaike (1973);

- the Schwarz Bayesian Information Criterion (BIC) proposed by Schwarz (1978);

- the Hannan-Quinn Information Criterion (HQC) proposed by Hannan and Quinn (1979).

If I_RGDP and 1_REXP are integrated at the first rank (meaning that both time series are non stationary while their first differences are stationary) we could study their long -run relationship by performing the Johansen (1988) tests of cointegration with constant and seasonal dummies as deterministic term. The regression associated to this method has the general form:

$$
\Delta Y_{t}=\Gamma_{0} \times D_{t}+\Pi \times Y_{t-1}+\sum_{j=1}^{k-1} \Gamma_{j} \times \Delta Y_{t-j}+\varepsilon_{t}
$$

where:

- $\quad \mathrm{Y}_{\mathrm{t}}$ is a vector containing the dependent variables;

- $\quad \mathrm{D}_{\mathrm{t}}$ is the vector of deterministic terms;

- $\quad \Gamma_{0}$ is a matrix of coefficients associated to deterministic terms;

- $\quad \Pi$ is a matrix of coefficients associated to one-lagged values of $Y_{t}$;

- $\quad \Gamma_{\mathrm{j}}$ is a matrix of coefficients associated to the $\mathrm{j}$-lagged values of $Y_{\mathrm{t}}$;

- $\quad \varepsilon_{\mathrm{t}}$ is a vector of error terms.

For the Johansen cointegration regression we chose the number of lags based on the same information criteria used for the ADF tests. The number of linearly independent and stationary linear combinations of the variables of $Y_{t}$ vector is equal to the rank $r$ of $\Pi$ matrix (Johansen \& Juselius, 1990; Johansen, 1995). The value of $r$ is used in two tests of cointegration: the trace test and the maximum eigenvalue $(\lambda-\max )$ test. For the trace test the null hypothesis is that are at most $r$ cointegrating vectors. In case of the maximum eigenvalue test the null hypothesis of $r$ cointegrating vectors is opposed to the alternative hypothesis of $\mathrm{r}+1$ cointegrating vectors.

If d_l_RGDP and d_l_REXP are stationary we could analyze the interactions between the two time series using two equations VAR models with constant and seasonal dummies as deterministic term. The first VAR equation, with d_l_RGDP as dependent variable, consists in:

$$
d_{-} l_{-} R G D P_{t}=\mathrm{const}+\sum_{j=1}^{k} \beta_{j} \times d_{-} l_{-} R G D P_{t-j}+\sum_{j=1}^{k} \chi_{j} \times d_{-} l_{-} R E X P_{t-j}+\sum_{l=1}^{3} \lambda_{l} \times S_{l}+\varepsilon_{t}
$$

where:

- $\mathrm{k}$ is the number of lags;

- $\beta_{\mathrm{k}}$ and $\chi_{\mathrm{k}}$ are coefficients of the k-lagged values of the two variables;

- $\mathrm{S}_{\mathrm{I}}$ is a seasonal dummy variable associated to the quarter $\mathrm{l}$;

$-\lambda_{1}$ is the coefficient of the seasonal dummy variable associated to the quarter l;

- $\varepsilon_{\mathrm{t}}$ is an error term. 
The second VAR equation, with d_l_REXP as dependent variable, consists in:

$$
d_{-} l_{-} R E X P_{t}=\mathrm{const}+\sum_{j=1}^{k} \varphi_{j} \times d_{-} l_{-} R G D P_{t-j}+\sum_{j=1}^{k} \gamma_{j} \times d_{-} l_{-} R E X P_{t-j}+\sum_{l=1}^{3} \lambda_{l} \times S_{l}+\theta_{t}
$$

where:

- $\varphi_{\mathrm{k}}$ and $\gamma_{\mathrm{k}}$ are the coefficients of the k-lagged values of the two variables;

- $\theta_{\mathrm{t}}$ is an error term.

We use the three information criteria (AIC, BIC and HQC) to chose the numbers of lags for VAR models.

Based on the VAR regressions we could determine the impulse - response functions which allow us to estimate the impact of the one-unit shock (a one-standard error increase) of d_l_RGDP or d_l_REXP to the future values of both variables (Lütkepohl \& Reimers, 1992; Stock \& Watson, 2001; Lütkepohl, 2011). In the VAR framework we could also study the Granger causalities between d_l_RGDP and d_l_REXP (Granger, 1969; Granger, 1988; Lütkepohl, 2011).

\section{Empirical Results}

We start by performing the ADF unit root tests for the four variables. The results, presented in the Table 1 indicate the nonstationarity of I_RGDP and l_REXP, while their first differences could be considered as stationary. We can conclude that both I_RGDP and 1_REXP are integrated at the first rank.

\begin{tabular}{|c|c|c|c|c|}
\hline Variable & $\begin{array}{l}\text { Deterministic } \\
\text { term }\end{array}$ & $\begin{array}{c}\text { Number of } \\
\text { lags }\end{array}$ & Test statistics & $\begin{array}{l}\text { Asymptotic } \\
\text { p-value }\end{array}$ \\
\hline \multirow[t]{2}{*}{ l_RGDP } & $\begin{array}{l}\text { constant and } \\
\text { trend plus }\end{array}$ & BIC, HQC: 1 & -2.51032 & 0.3231 \\
\hline & $\begin{array}{l}\text { seasonal } \\
\text { dummies }\end{array}$ & AIC:2 & -1.46314 & 0.5525 \\
\hline l_REXP & $\begin{array}{l}\text { constant and } \\
\text { trend plus } \\
\text { seasonal } \\
\text { dummies }\end{array}$ & $\begin{array}{c}\text { AIC, BIC, HQC: } \\
1\end{array}$ & -2.84117 & 0.1823 \\
\hline \multirow{2}{*}{ d_l_RGDP } & $\begin{array}{l}\text { constant plus } \\
\text { seasonal }\end{array}$ & BIC, HQC: 1 & -4.73681 & $0.000001^{* * *}$ \\
\hline & dummies & AIC:2 & -3.72675 & $0.003771^{* * *}$ \\
\hline \multirow[t]{2}{*}{ d_l_REXP } & constant plus & BIC:1 & -3.51738 & $0.008259 * * *$ \\
\hline & dummies & HQ, AIC: 3 & -3.53063 & $0.007266^{* * *}$ \\
\hline
\end{tabular}

Note: $* * *$ means significant at 0.01 level.

The results of the Johansen cointegration method are reported in the Table 2. The p-values associated to the trace tests and to the $\lambda$ - max tests couldn't support the hypothesis of cointegration between l_RGDP and l_REXP.

Table 2. Results of Johansen cointegration tests

\begin{tabular}{ccccc} 
Number of lags & Rank & Eigenvalue & Trace test & $\lambda$ - max test \\
& 0 & 0.34487 & 13.382 & 13.111 \\
BIC, HQC: 1 & & & {$[0.1013]$} & {$\left[0.0742^{*}\right]$} \\
& \multirow{2}{*}{1} & 0.0087132 & 0.27129 & 0.27129 \\
& \multirow{2}{*}{0} & 0.29371 & {$[0.6025]$} & {$[0.6025]$} \\
AIC:2 & \multirow{2}{*}{1} & 0.038936 & 11.623 & 10.432 \\
& & & 1.1914 & {$[0.1883]$} \\
& & & {$[0.2750]$} & {$[0.1914$} \\
& & & &
\end{tabular}

Notes: p-values are within squared brackets; * means significant at 0.1 level.

Since d_l_RGDP and d_l_REXP are stationary we could employ them in VAR models to study their interactions. We identify the optimum number of the lags for VAR regressions using the three criterions AIC, BIC and HQC. BIC criterion indicates a single lag, while AIC and HQC criteria indicate three lags.

Table 3. The optimum number of lags for the VAR models 
Number of lags

$$
1
$$$$
2
$$

3
AIC

$-5.503886$

$-5.611420$

$-5.718654^{*}$

\section{Criterion}

BIC

$-4.932941^{*}$

$-4.850160$

$-4.767080$
HQC

$-5.329342$

$-5.378695$

$-5.427748^{*}$

Note: The asterisks indicate the best values of the respective information criteria.

We perform the regressions of a VAR model with one lag. For the first equation (with d_l_RGDP as dependent variable) we find significant positive coefficients of the constant term and of the one-lagged values of d_l_REXP. We also obtain a significant negative coefficient of the seasonal dummy variable $S_{1}$ (Table 4).

Table 4. The first equation (with d_l_RGDP as dependent variable) of a VAR model with one lag

\begin{tabular}{|c|c|c|c|c|}
\hline Variable & Coefficient & Std. Error & t-ratio & p-value \\
\hline const & 0.101231 & 0.0396181 & 2.5552 & $0.01737^{* *}$ \\
\hline _l_RGDP_1 & -0.104185 & 0.18683 & -0.5576 & 0.58225 \\
\hline d_l_REXP_1 & 0.492081 & 0.200196 & 2.4580 & $0.02157^{* *}$ \\
\hline S1 & -0.560773 & 0.0334942 & -16.7424 & $0.00001^{* * *}$ \\
\hline S2 & 0.0566753 & 0.122385 & 0.4631 & 0.64747 \\
\hline S3 & 0.0822915 & 0.0293183 & 2.8068 & $0.00977^{* * *}$ \\
\hline
\end{tabular}

Note: ${ }^{* *}$ and ${ }^{* * *}$ mean significant at 0.05 and 0.01 , respectively, levels.

The results of the second equation (with d_l_REXP as dependent variable) indicate a significant positive coefficient of the one-lagged values of d_l_REXP (Table 5).

Table 5. The second equation (with d_l_REXP as dependent variable) of a VAR model with one lag

\begin{tabular}{|c|c|c|c|c|}
\hline Variable & Coefficient & Std. Error & t-ratio & $\mathrm{p}$-value \\
\hline const & 0.00927625 & 0.0377183 & 0.2459 & 0.80782 \\
\hline d_l_RGDP_1 & -0.0939689 & 0.177871 & -0.5283 & 0.60214 \\
\hline d_l_REXP_1 & 0.411972 & 0.190596 & 2.1615 & $0.04085^{* *}$ \\
\hline $\mathrm{S} 1$ & -0.0374559 & 0.0318881 & -1.1746 & 0.25168 \\
\hline S2 & 0.0204205 & 0.116516 & 0.1753 & 0.86235 \\
\hline S3 & 0.0353151 & 0.0279124 & 1.2652 & 0.21794 \\
\hline
\end{tabular}

Note: ** means significant at 0.05 levels.

The Figure 2 presents the Impulse - Response functions associated to the VAR model with one lag. A one-standard error increase of d_l_RGDP leads to rather insignificant variation of the two variables future values (Table 6).

Table 6. Responses to a one-standard error shock in d_l_RGDP for a VAR model with one lag

$\begin{array}{ccc}\text { Period } & \text { d_l_REXP } & \text { d_l_RGDP } \\ 1 & 0 & 0.051408 \\ 2 & -0.0048308 & -0.0053559 \\ 3 & -0.0014868 & -0.0018191 \\ 4 & -0.0004416 & -0.00054212\end{array}$

The reactions to a one-standard error shock in d_l_REXP, presented in the Table 7, suggest a significant impact of d_l_REXP to d_l_RGDP.

Table 7. Responses to a one-standard error shock in d_l_REXP for a VAR model with one lag

$\begin{array}{ccc}\text { Period } & \text { d___REXP } & \text { d_l_RGDP } \\ 1 & 0.049815 & 0.0097457 \\ 2 & 0.019606 & 0.023497 \\ 3 & 0.0058693 & 0.0071999 \\ 4 & 0.0017414 & 0.002138\end{array}$

The results of Granger causality tests between the two variables, reported in the Table 8, indicate a significant causality from d_l_REXP to d_l_RGDP, while the null hypothesis that d_l_RGDP do not Grangercause d_l_REXP couldn't be rejected. 
Table 8. Results of the Granger causality tests for a VAR model with one lag

Null hypothesis

"d_l_REXP" do not Granger-cause

"d_l_RGDP"

"d_l_RGDP" do not Granger-cause

$$
\text { "d_l_REXP" }
$$

Note: ${ }^{* *}$ means significant at 0.05 levels.

\section{F-statistic \\ 6.0417}

0.2791 p-value

$0.0176^{* *}$

0.5997

We continue by employing a VAR model with three lags. For the first equation (with d_l_RGDP as dependent variable) resulted significant positive coefficients for the constant term and for all lagged values of d_l_REXP. We also obtained significant negative coefficients for all the lagged values of d_l_RGDP (Table 9).

d_I_RGDP - > d_I_RGDP

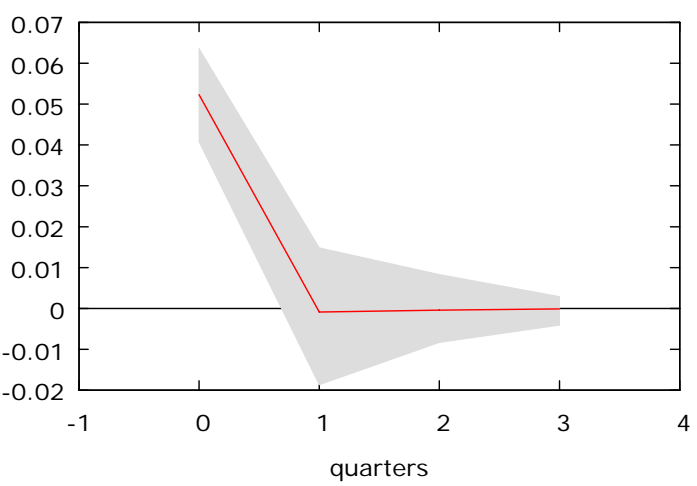

d_I_RGDP - > d_I_REXP

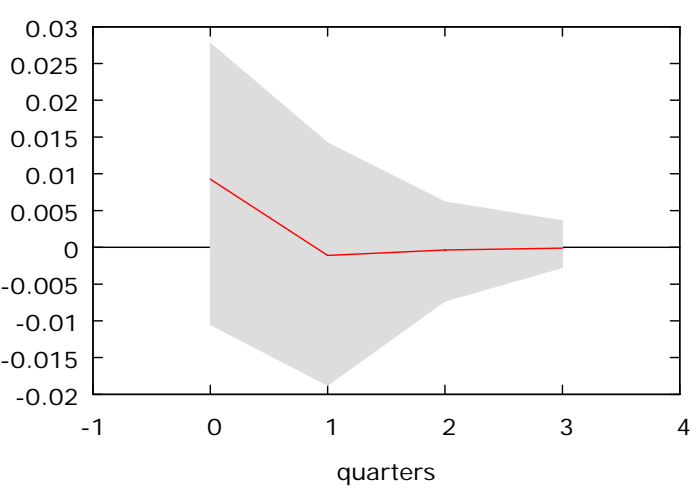

d_I_REXP - > d_I_RGDP

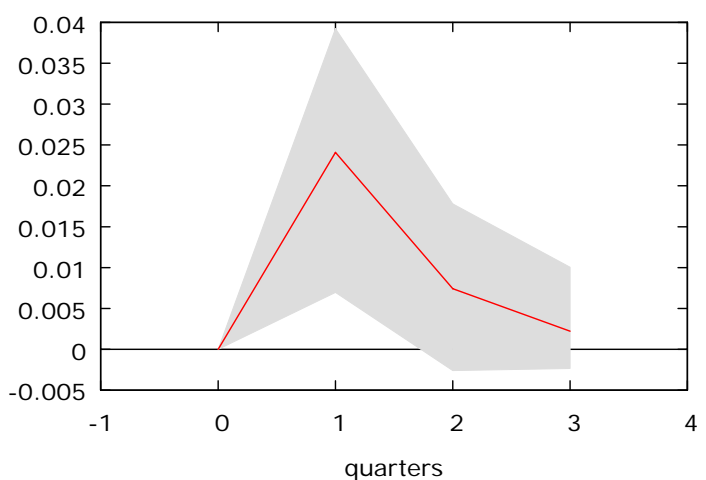

d_I_REXP - > d_I_REXP

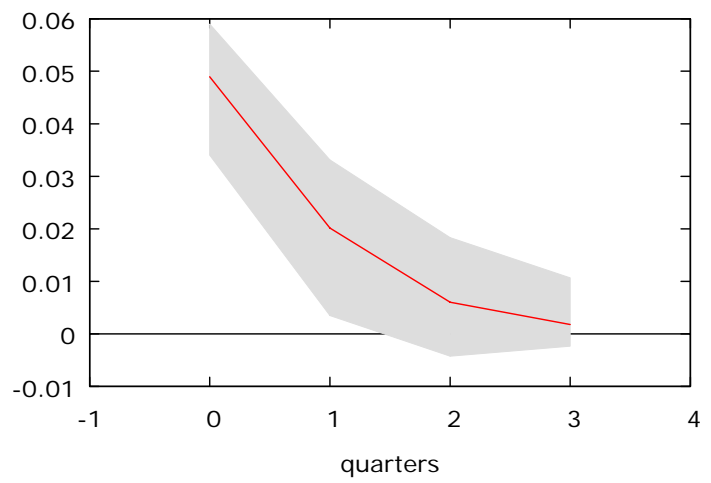

Figure 2. Impulse - Response functions of a VAR model with one lag

Table 9. The first equation (with d_l_RGDP as dependent variable) of a VAR model

\begin{tabular}{|c|c|c|c|c|}
\hline \multicolumn{5}{|c|}{ with three lags } \\
\hline \multirow{2}{*}{$\begin{array}{c}\text { Variable } \\
\text { const }\end{array}$} & Coefficient & Std. Error & t-ratio & p-value \\
\hline & 0.169569 & 0.0702595 & 2.4135 & $0.02668^{* *}$ \\
\hline d_l_RGDP_1 & -0.613346 & 0.184499 & -3.3244 & $0.00377^{* * *}$ \\
\hline d_l_RGDP_2 & -0.628828 & 0.164176 & -3.8302 & $0.00123^{* * *}$ \\
\hline d_l_RGDP_3 & -0.269514 & 0.151743 & -1.7761 & $0.09262 *$ \\
\hline d_l_REXP_1 & 0.558806 & 0.166791 & 3.3503 & $0.00356^{* * *}$ \\
\hline d_l_REXP_2 & 0.394386 & 0.205152 & 1.9224 & $0.07053^{*}$ \\
\hline d_l_REXP_3 & 0.448471 & 0.18569 & 2.4152 & 0.02659 ** \\
\hline $\mathrm{S} 1$ & -0.445416 & 0.0950855 & -4.6844 & $0.00018^{* * *}$ \\
\hline S2 & -0.151482 & 0.122818 & -1.2334 & 0.23330 \\
\hline S3 & -0.163163 & 0.125238 & -1.3028 & 0.20906 \\
\hline
\end{tabular}

Note: ** means significant at 0.05 levels. 
The Table 10 presents the parameters of the second equation (with d_l_REXP as dependent variable). We identify a significant positive coefficient for the first lagged value of d_l_REXP.

Table 10. The second equation (with d_l_REXP as dependent variable) of a VAR model

\begin{tabular}{|c|c|c|c|c|}
\hline & & vith three lag & & \\
\hline Variable & Coefficient & Std. Error & t-ratio & $\mathrm{p}$-value \\
\hline const & 0.0687099 & 0.0986963 & 0.6962 & 0.49521 \\
\hline d_l_RGDP_1 & -0.0336618 & 0.259173 & -0.1299 & 0.89810 \\
\hline d_l_RGDP_2 & -0.0138941 & 0.230624 & -0.0602 & 0.95262 \\
\hline d_l_RGDP_3 & 0.150641 & 0.213159 & 0.7067 & 0.48880 \\
\hline d_l_REXP_1 & 0.491056 & 0.234298 & 2.0959 & $0.05050 *$ \\
\hline d_l_REXP_2 & -0.147047 & 0.288185 & -0.5103 & 0.61607 \\
\hline d_l_REXP_3 & -0.126399 & 0.260846 & -0.4846 & 0.63382 \\
\hline S1 & -0.117939 & 0.13357 & -0.8830 & 0.38889 \\
\hline S2 & -0.0275776 & 0.172527 & -0.1598 & 0.87478 \\
\hline S3 & -0.0732599 & 0.175927 & -0.4164 & 0.68202 \\
\hline
\end{tabular}

Note: ** means significant at 0.05 levels.

The Impulse - Response functions associated to the VAR model with three lags are presented in the Figure 3. The responses to the one-standard error shock in d_l_RGDP couldn't be considered as significant (Table 11).
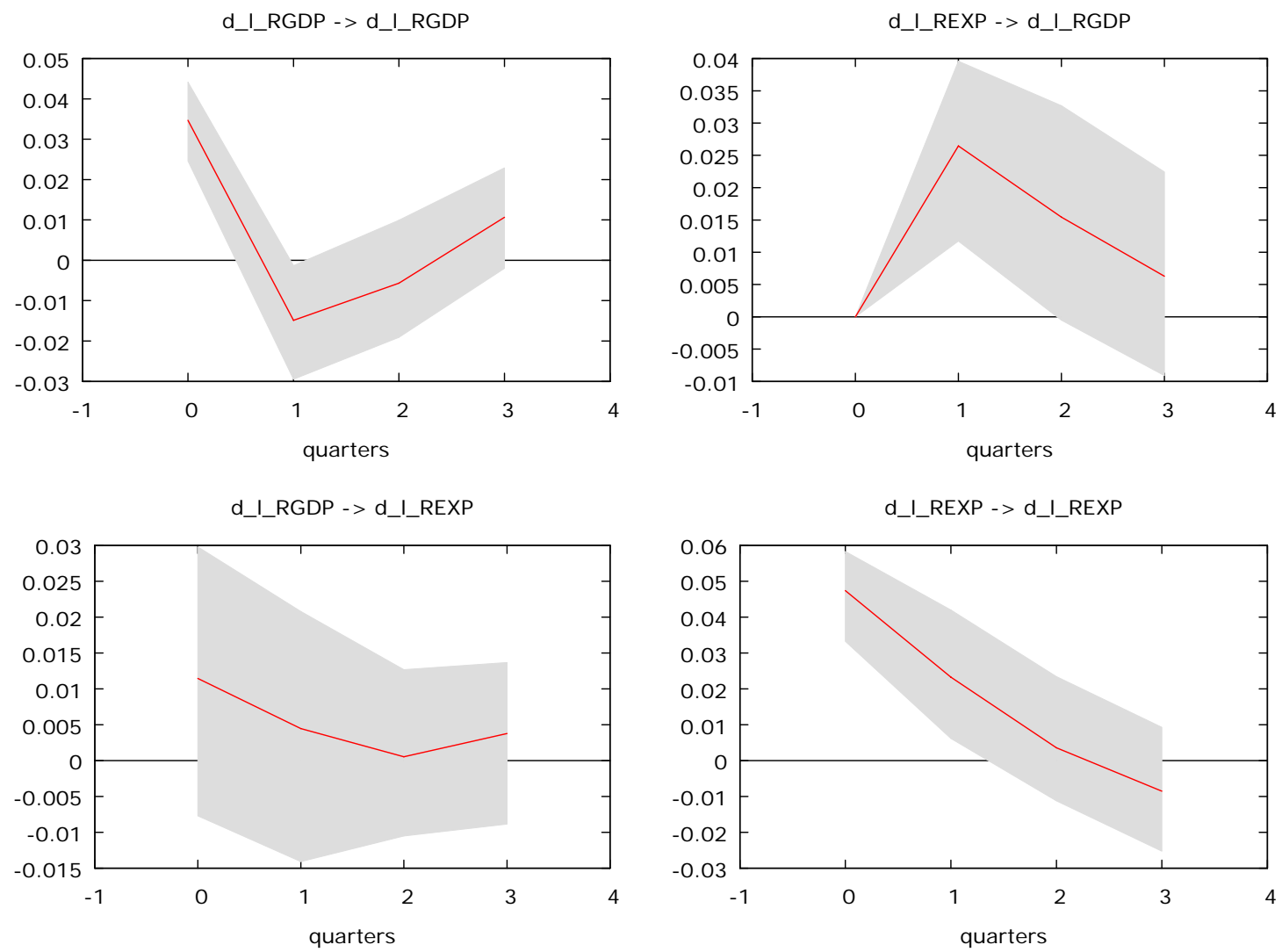

Figure 3. Impulse - Response functions of a VAR model with three lags

Table 11. Responses to a one-standard error shock in d_l_RGDP for a VAR model with three lags

$\begin{array}{ccc}\text { Period } & \text { d_l_REXP } & \text { d_l_RGDP } \\ 1 & 0 & 0.033712 \\ 2 & -0.0011348 & -0.020677 \\ 3 & -0.00032962 & -0.009151\end{array}$


The Table 12 reports the reactions to a one-standard error shock in d_l_REXP. Their values suggest a significant impact of d_l_REXP on d_l_RGDP.

Table 12. Responses to a one-standard error shock in d_l_REXP for a VAR model with three lags

$\begin{array}{ccc}\text { Period } & \text { d_l_REXP } & \text { d_l_RGDP } \\ 1 & 0.048724 & 0.0081586 \\ 2 & 0.023651 & 0.022223 \\ 3 & 0.0035881 & 0.013672 \\ 4 & -0.0074145 & 0.0086252\end{array}$

The Granger causality tests indicate a unidirectional causality: d_l_REXP Granger-cause d_l_RGDP, while d_l_RGDP do not Granger-cause d_l_REXP (Table 13).

Table 13. Results of the Granger causality tests for a VAR model with three lags

Null hypothesis

"d_l_REXP" do not Granger-cause "d_l_RGDP"

"d_l_RGDP" do not Granger-cause "d_l_REXP"

\section{F-statistic}

9.2507

0.2330 p-value

$0.0001^{* * *}$

0.8728

Note: *** means significant at 0.01 levels.

\section{Conclusions}

In this paper we investigated the relationship between Romanian exports and GDP between 2007 and 2014 using Johansen cointegration method, VAR models and Granger causality tests. The cointegration tests didn't provide evidences in favor of a stable long-run relationship between the two variables. The VAR models indicated a significant impact of real exports on real GDP. We also found a significant Granger causality from real exports to real GDP.

These results could be considered as arguments in favor of ELGH, meaning that export could be considered as an efficient tool for economic growth. However, Romania's adhesion to European Union generated some constraints to exports promotion. The classical forms of export subsidies are prohibited and Romania's objective of adhesion to the European Monetary Union affects its foreign exchange policy. In these circumstances the government policies to stimulate exports should be directed to the foreign direct investments promotion, to activities of training and consultancy offered to exporters or to efforts of encouraging domestic firms to sale their production on the foreign markets.

This investigation could be extended to the study of relationship between economic growth and other elements of foreign trade, such as imports or foreign direct investments.

\section{References}

1. Abbas, S. (2012), "Causality between exports and economic growth: investigating suitable trade policy for Pakistan", Eurasian Journal of Business and Economics, 5(10), pp. 91-98.

2. Ahmad, J., \& Harnhirun, S. (1996), "Cointegration and causality between exports and economic growth: evidence from the ASEAN countries", Canadian Journal of Economics, S413-S416.

3. Akaike, H. (1969), "Fitting autoregressive models for prediction", Annals of the Institute of Statistical Mathematics 21, pp. 243-247.

4. Akaike, H. (1973), "Information theory and an extension of the maximum likelihood principle", in B. Petrov and F. Csáki (eds), 2nd International Symposium on Information Theory, Académiai Kiadó, Budapest, pp. 267-281.

5. Akaike, H. (1974), "A new look at the statistical model identification", IEEE Transactions on Automatic Control AC19, pp. 716-723.

6. Aw, B. Y. \& Chung, S., \& Roberts, M. J. (1998), "Productivity and the decision to export: micro evidence from Taiwan and South Korea", NBER Working Paper No. 6558

7. Bahmani-Oskooee, M. \& Alse, J. (1993), "Export growth and economic growth: An application of cointegration and error-correction modeling", The Journal of Developing Areas, pp. 535-542.

8. Bahmani-Oskooee, M. \& Economidou, C. (2009), "Export led growth vs. growth led exports: LDCs experience", The Journal of Developing Areas, pp. 179-212.

9. Balassa, B. (1978), "Exports and economic growth: Further evidence", Journal of Development Economics, 5, 2 (June), pp. 181-189.

10. Barro, R.J. (1991), "Economic Growth in a Cross-Section of Countries", Quarterly Journal of Economics, 106 (2), pp. 407-443. 
11. Bernard, A. B. \& Jensen, J. B. (1999), "Exceptional exporter performance: cause, effect, or both?", Journal of international economics, 47(1), 1-25.

12. Bhagwati, J. \& Srinivasan, T. (1979), "Trade Policy and Development" in: Dornbush and Frenkel (eds), International Economic Policy: Theory and Evidence, Baltimore: Johns Hopkins University Press.

13. Bhagwati J.N. (1988), "Protectionism", MIT Press, Cambridge, Massachusetts.

14. Clerides, S. \& Lach, S. \& Tybout, J. (1996), "Is learning-by-exporting important? Micro-dynamic evidence from Colombia, Mexico and Morocco", NBER Working Paper No. 5715

15. De Loecker, J. (2010), "A note on detecting learning by exporting", NBER Working Paper No. 16548

16. Dickey, D. A. \& Fuller, W. A. (1979), "Estimators for autoregressive time series with a unit root", Journal of the American Statistical Association 74, pp. 427-431

17. Dritsakis, N. \& Varelas, E. \& Adamopoulos, A. (2006), "The main determinants of economic growth: An empirical investigation with Granger causality analysis for Greece", European Research Studies Journal, 9(3-4), pp. 47-58.

18. Dumitriu, R. \& Stefanescu, R. \& Nistor, C. (2010), "Exports as an engine for the economic growth: the case of Romania", Vanguard Scientific Instruments in Management, Vol. 3, pp. 303-309.

19. Emery, R. F. (1967), "The relation of exports and economic growth", Kyklos, 20, 2 (May): 470-86.

20. Granger, C.W.J. (1969), "Investigating causal relations by econometric models and cross spectral methods", Econometrica, 37, pp. 424-38.

21. Granger, C.W.J. (1988), "Some recent developments in the concept of causality", Journal of Econometrics, 39, pp. 199211.

22. Hannan, E. J. \& Quinn, B. G. (1979), "The determination of the order of an autoregression", Journal of the Royal Statistical Society B41: pp. 190-195.

23. Helpman, E. \& Krugman, P. (1985), "Market Structure and Foreign Trade", Cambridge, MA: MIT Press.

24. Helpman, E. (1999), "The Structure of Foreign Trade", The Journal of Economic Perspectives, 13(2), pp. 121-144.

25. Johansen, S. (1988), "Statistical analysis of cointegration vectors", Journal of economic dynamics and control, 12(2), pp. 231-254.

26. Johansen, S. (1991), "Estimation and hypothesis testing of cointegration vectors in Gaussian vector autoregressive models", Econometrica: Journal of the Econometric Society, pp. 1551-1580.

27. Johansen, S. (1995), "Likelihood-Based Inference in Cointegrated Vector Autoregressive Models", Oxford University Press, Oxford

28. Johansen, S. \& Juselius, K. (1990), "Maximum likelihood estimation and inference on cointegration-with applications to the demand for money", Oxford Bulletin of Economics and statistics, 52(2), pp. 169-210.

29. Jung, W. S. \& Marshall, P. J. (1985), "Exports, growth and causality in developing countries", Journal of development economics, 18(1), 1-12.

30. Keynes J. M. (1935), "The General Theory of Employment, Interest and Money"

31. http://gutenberg.net.au/ebooks03/0300071h/printall.html

32. Kravis, I. B. (1970), "Trade as a handmaiden of growth: Similarities between the nineteenth and twentieth centuries", Economic Journal, 80, 320 (December): 850-72.

33. Krugman, P.R. (1980), "Scale economies, product differentiation, and the pattern of trade", The American Economic Review, 950-959.

34. Krugman, P.R. (1984), "Import protection as export promotion", In: Kierzkowski, H. (Ed.), Monopolistic Competition in International Trade, Oxford University Press, Oxford.

35. Kugler, P. (1991), "Growth, Exports and Cointegration: An Empirical Investigation", Weltwirtschaftliches Archiv, Bd. 127, H. 1 (1991), pp. 73-82.

36. Lütkepohl, H. \& Reimers, H. E. (1992), "Impulse response analysis of cointegrated systems", Journal of economic dynamics and control, 16(1), pp. 53-78.

37. Lütkepohl, H. (2011), "Vector Autoregressive Models", Springer Berlin Heidelberg, pp. 1645-1647

38. Marin, D. (1992), "Is the export-led growth hypothesis valid for industrialized countries?", The Review of Economics and Statistics, pp. 678-688.

39. Mehrara, M. \& Firouzjaee, B. A. (2011), "Granger causality relationship between export growth and GDP growth in developing countries: panel cointegration approach", International Journal of Humanities and Social Science, 1(16), pp. 223-231.

40. Michaely, M. (1977), "Exports and growth: An empirical investigation", Journal of Development Economics, 4, 1 (March), pp. 49-53.

41. Pop Silaghi, M. I. (2009), "Exports-economic growth causality: Evidence from CEE countries", Journal for Economic Forecasting, 6(2), pp. 105-117.

42. Ricardo, D. (1817), "On the Principles of Political Economy, and Taxation"

43. http://www.gutenberg.org/files/33310/33310-h/33310-h.htm

44. Rodrik, D. (1988), “Closing the technology gap: Does trade liberalization really help?”, NBER Working Paper No. 2654

45. Schank, T. \& Schnabel, C. \& Wagner, J. (2008), "Higher wages in exporting firms: self-selection, export effect, or both? First evidence from linked employer-employee data", IZA Discussion Paper No. 3359

46. Schwarz, G. (1978), "Estimating the dimension of a model", Annals of Statistics 6, pp. 461-464.

47. Sims, C. A. (1980), "Macroeconomics and reality", Econometrica: Journal of the Econometric Society, 1-48.

48. Serven, A. K. (1968), "The relation of exports and economic growth: Comment", Kyklos, 21, 3 (August): 546-48.

49. Sharma, S. C. \& Dhakal, D. (1994), "Causal analyses between exports and economic growth in developing countries", Applied Economics, 26(12), pp. 1145-1157.

50. Smith, Adam (1776), "An Inquiry into the Nature and Causes of the Wealth of Nations" 
International Conference "Risk in Contemporary Economy” ISSN-L 2067-0532 ISSN online 2344-5386 XVIth Edition, 2015, Galati, Romania,

"Dunarea de Jos" University of Galati - Faculty of Economics and Business Administration

51. http://www.gutenberg.org/files/3300/3300-h/3300-h.htm

52. Sokoloff, K. L. (1984), "Was the transition from the artisanal shop to the nonmechanized factory associated with gains in efficiency?: Evidence from the US Manufacturing censuses of 1820 and 1850", Explorations in Economic History, 21(4), pp. 351-382.

53. Stefanescu, R. \& Dumitriu, R. \& Nistor, C. (2010), "Evolution of the Romanian Exports and Imports in the Context of the European Integration", Proceedings of the 16th International Conference "The Knowledge-Based Organization", "Nicolae Bălcescu" Land Forces Academy, 25-27 November 2010.

54. Stefanescu, R. \& Dumitriu, R. (2014), "Investigation on the Relationship between Romanian Foreign Trade and Industrial Production", Vanguard Scientific Instruments In Management, vol. 1 (9) / December 2014, pp. 101-113.

55. Stock, J. H. \& Watson, M. W. (2001), "Vector autoregressions", Journal of Economic perspectives, pp. 101-115.

56. Syron, R. F. \& Walsh, B. M. (1968), "The relation of exports and economic growth: A note", Kyklos, 21, 3 (August), pp. 541-545.

57. Voivodas, C. S. (1973), "Exports, foreign capital inflow and economic growth", Journal of International Economics, 3(4), pp. 337-349.

58. Wagner, J. (2005), "Exports and productivity: A survey of the evidence from firm level data", HWWA, Discussion Paper No. 319. 